\title{
Exploring Funding in Higher Education to Eliminate Poverty in South Africa
}

\section{Prof CM van der Bank}

\author{
Human Sciences, Vaal University of Technology
} riana@vut.ac.za

\section{MR Nkadimeng}

Vaal University of Technology nkadimeng.mohlahledi@gmail.com

\author{
Doi:10.5901/ajis.2014.v3n1p353
}

\begin{abstract}
Since South Africa's transition from apartheid to a democratic government in 1994, the country has been struggling to bridge the inequalities between the rich and the poor and youth unemployment has reached alarmingly high levels. However indicators demonstrate that youth unemployment and poverty are as a result of limited access to higher education amongst the previously disadvantaged groups. It is also observable that a massive number of students drop-out of higher education due to exorbitant study costs. Therefore it is relevant to explore the funding model and need for free tertiary education as articulated by various scholars and academics to enable the country to deal with the socio-economic challenges stifling its growth.
\end{abstract}

Keywords: Funding model, free higher education, access, funding, unemployment, poverty, NSFAS, previously disadvantaged, drop-out

\section{Introduction}

Increasing access to higher education remains a challenge in many African countries and South Africa is no exception. South Africa has 23 public universities, however access to higher education remains a challenge given the poverty and unemployment levels amongst the previously disadvantaged groups. The disparities between different race groups is documented in Wangenge-Ouma (2012:3) as the author points out that while the black population accounts for about $80 \%$ of the total South African population, its higher education participation rate is $12 \%$, compared for example to the white population group with a $60 \%$ participation rate, but an overall population representation of $9 \%$. The South African Student Congress (SASCO) and other students' organisations have been vocal through the years advocating for free higher education for the poor until the attainment of an undergraduate qualification.

However having outlined these challenges, it is also important to acknowledge that the government of the Republic of South Africa has made advances in expanding access in higher education since 1995, most notably towards the previously disadvantaged groups through the establishment and implementation of the National Student Financial Aid Scheme (NSFAS). NSFAS was established under the NSFAS Act No 56 of 1999 aimed at providing financial aid to eligible students who meet the criteria for admission to a higher education programme. An NSFAS presentation to the portfolio committee on Higher Education titled 'NSFAS transformation programme-' showed a remarkable increase in funding from 1999- 2012. The document demonstrates substantial increase from R441 million in 1999 to R6 billion in 2011 and to R5.7 billion in 2012 (NSFAS, 2012). However while NSFAS has been successful there is strong evidence to suggest the need for free higher education to deserving citizens as this will ultimately lead to the elimination of poverty and bridge the gap between the rich and the poor in the country.

\section{Problem Statement}

Higher education fees are arguably expensive and poses insurmountable barrier to many South Africans wishing to pursue education beyond Matric level. Given the poverty levels in South Africa the discourse on free higher education for poverty alleviation has been of paramount importance. According to Statistics South Africa (2011) in 2009 national poverty levels were recorded at $56.8 \%$. Poverty has a negative impact in that it denies people access to education while the majority of graduates and drop-outs incurred massive debts as a result. According to Higher Education South Africa 
(HESA) student debt in higher education was believed to be at R2.8 billion (HESA, 2010). The latter view from HESA depicts higher education in South Africa as an expensive commodity and unaffordable to many impoverished citizens.

Statistics South Africa (2011) has outlined that "Having tertiary education-particularly a degree-increases one's chances of getting a job". According to the organisation the unemployment rate among graduates was $5,2 \%$ and that of persons with other tertiary qualifications (diplomas or certificates) was $12,6 \%$. In contrast the rate was $30,3 \%$ among those without Matric (STATSSA, 2011). In essence there is strong evidence to suggest that free higher education is a desirable vehicle to address the socio-economic challenges and the legacy of apartheid in South Africa (HESA, 2010, STATSA, 2011, DHET, 2012).

- What are higher education costs in South Africa?

- Why is NSFAS not working?

- Why must government implement free higher education?

- How will this impact on poverty and unemployment?

\section{Aims of the Study are to:}

The primary objective of this paper is to examine possible ways in which the government of the Republic of South Africa can implement free higher education for undergraduate qualifications. This paper positions an argument which suggests that implementing free higher education in South Africa can lead to poverty alleviation and reduction in unemployment levels. The paper will interrogate the feasibility of implementing free higher education by answering the questions that have been raised.

\section{Literature Review}

\subsection{Current barriers}

Firstly it is fundamental to lay the grounds by demonstrating that the African National Congress, which is the ruling party in South Africa. Recognised at its $52^{\text {nd }}$ National Congress in Polokwane that education was a key pillar for social transformation. Furthermore a resolution was adopted at this conference to progressively introduce free education for the poor until undergraduate level (ANC, 2007). However, despite this resolution being put forward at the conference, it has not resulted in a policy framework at the current stage and most underprivileged South Africans continue to be sidelined by high registration fees and study fees at most higher education institutions.

\subsubsection{Study costs in higher education and consequences for poor households}

Forward payments or registration fees are seen by many as a stumbling block for previously disadvantaged South Africans wishing to access higher education. According to the 'Green Paper for Post- School Education and Training' "there are inadequate financial resources to allow most school leavers, including Matriculants, to successfully enter postschool provision" (DHET, 2012:9). The latter view is supported by De Villiers (2012:56-57) who demonstrate that higher education institutions have come under more financial constraints and have had to increase fees (in real terms). The author further adds that unfortunately this had negative consequences for prospective students from poor communities because it has made higher education more unaffordable to the poor (De Villiers, 2012: 57). Accordingly most South African universities charge upfront fees costing above R 2000 whereas an average annual expenditure for an objectively poor South African house hold according to STATS SA stands at R23 266 per annum (STATSSA, 2012:38). One can then argue that the disparities in the cost of higher education and poverty levels perpetuate the slow pace of social transformation and poverty elevation experienced in recent years. De Villiers (2012:57) then presents that "while universities were expected to become more inclusive in terms of attracting a more diverse student profile, these inevitable cost increases became a prohibitive factor for poor students to enter the system". The burden of debts sustained by poor households in their quest to access higher education denies many the opportunities to achieve the desired social and economic privileges. Another challenge highlighted by the Green Paper demonstrates constraints in post-school education including, amongst others, inadequate financial resourcing and insufficient financial aid for students (DHET, 2012:9-10). The damning consequences result in many students from poor households' dropping-out before completion of their qualifications.

The alarming drop-out rates due to financial constraints or student debts was noted in a document titled Draft 
National Plan for Higher Education in South Africa. The document depicts that "On average, about 20\% of all undergraduates and postgraduates drop- out of the higher education system each year. The average for first-time entering students is $25 \%$. This result in an annual loss to the system of at least 120000 students who do not complete their studies" (Department of Education: 2001:18). The International Education Association of South Africa (IEASA) concurs by highlighting that higher education has a disturbing 45\% drop-out rate among students, undermining the access gains of universities. The statement further alerts that financial difficulties among the country's large pool of poor black students are largely to blame (IEASA, n.d:16). In essence there is a plethora of evidence to demonstrate that South African Higher Education is unaffordable to poor households which has a direct negative impact on the economic development of the country. Thus one can also argue that the current state of affairs warrants strong political intervention in favour of poor households. A survey by the Human Science Research Council shows that $70 \%$ of higher education drop-outs were in the low income category (Letseka and Maile, 2008:6).

\subsection{The National Student Financial Aid Scheme (NSFAS)}

The NSFAS has been moderately successful in bridging the gap between the previously disadvantaged and the previously advantaged. However while it does not cater for full tertiary costs, it is also burdened by the increasing number of students entering the higher education system. Firstly, one of the prominent challenges faced by students who are granted NSFAS funding, is outlined by Mdepa and Tshiwula (2012:24) who demonstrate that the loans offered do not cover living expenses. Access is therefore still hindered in cases where students live far away from campuses and cannot afford to cover these expenses themselves. Given some of the socio-economic challenges that have already been outlined, one can concur with Mdepa and Tshiwula in that the NSFAS funding provides little relief for students coming from poor households as it does not cover all the study costs but selective costs based on available funds. The Green Paper for Post-School Education concurs by maintaining that "demand for financial aid is outstripping the amounts available through the National Student Financial Aid Scheme (NSFAS)". The paper further demonstrates that research indicates that more than $25 \%$ of the total student undergraduate population at universities is on financial aid, and the demand is still unfulfilled and is rising" (Department of Higher Education and Training, 2012:12). NSFAS still has some structural problems preventing greater access of deserving students from poor households. Social and economic transformation cannot be attained if the funding model for higher education is not redirected in accordance with the social realities facing the country.

The ineffectiveness of NSFAS loans is also reflected in 'The Report of the Ministerial Committee on the Review of the National Student Financial Aid Scheme. The ministerial committee discovered some discrepancies in student funding in that a number of institutions still insist that students pay registration fees, either in part or in full, and amounting to several thousand rands, despite the NSFAS provision. The report further adds that the inability of NSFAS to regulate or monitor this behaviour by institutions contributes to student dissatisfaction with the scheme and must be addressed (DHET, 2010:43). To add onto the report by the ministerial committee one can position that the monitoring system of NSFAS and the respective institutions responsible for allocations need to be effective as it often leads to student dissatisfaction and student drop-outs as alluded to earlier.

It is also evident from the ministerial committee report that, for example in 2008 not a single institution managed to allocate NSFAS funding to cover full costs of study. The report further adds that only five universities were able to allocate more than $50 \%$ of what was needed to cover the full cost of study (DHET, 2010). This gap between what NSFAS pays and what total study fees amount to remain unresolved and continue to marginalise those who cannot afford to pay for themselves. Furthermore the DHET (2010:69) shows that of the 67\% of NSFAS students who are no longer studying, 28 percent have thus graduated and 72 percent have either dropped out or have not completed their studies. These indications of underperformance by NSFAS always lead to the most intriguing debate on the introduction of a free higher education for the poor up to an undergraduate qualification.

\subsection{The philosophy of free education}

While many may regard the debate on free higher education for the poor as a political rhetoric, one must acknowledge that the social problems in South Africa are not to be ignored. The fundamental issue at hand should be what must be done to make higher education accessible to the poor. Lubisi (2008:6) during the 'Solomon Mahlangu Memorial Lecture' outlined where the principle and aspiration for free education emanates from. The author stated that central to the ideology of free education is the requisites that it should firstly be funded through public taxes and secondly that the 
students or parents should not pay end-user fees to be educated at public institutions.

While there is little information about how free education can be implemented, its relevance to the current conditions cannot be over-emphasised. From a political perspective Lubisi (2008:6) further demonstrates that the notion of education as a private good has its roots in libertarianism, an ideology that (over)-emphasises individual freedom, and seeks to reduce the state and its role to a minimum. Then the author adds that concomitantly, education is seen as a commodity that should be sold and bought in the marketplace. End-user fees are seen in this context as the price that should be paid by the consumer for education in its commodified form (Lubisi, 2008:6). From an egalitarian point of view one can concur with Lubisi, because for South Africa to succeed, it is fundamental to have a classless higher education to empower the nation with necessary skills.

However while the political perspective does maintain a strong argument it is fundamental to consider other consenting philosophies. Letseka and Maile (2008:7) from the 'Human Science Reach Council' argue that students whose families are depend on social- grants need more financial assistance than what NSFAS currently offers. The authors then add that unless South Africa addresses issues of poverty and inequality, it is unlikely that the high drop-out rates and underrepresentation of black African students will improve (Letseka and Maile, 2008:7). In essence it is relevant to present that given South Africa's historical legacy, a higher education which is commodified can only breed greater inequalities. The progress which has been made through the NSFAS funding needs to be advanced to deal with the current barriers preventing children from poor households' access to higher education.

\section{Findings}

Several organisations and some organs of state have in recent years called for free higher education for the poor. In review the paper firstly presents a complex background of the economic and social challenges in South Africa and how they correlate with the current funding challenges in higher education. The paper then depicts an intertwined relationship between higher education fees, poverty and the effect it has on low income households in pursuit of higher education. With poverty considered to be standing at $56.8 \%$ it appears that most South Africans are unlikely to afford high education fees required to study at tertiary level. Another fundamental issue arising from the paper is that while a tertiary qualification is likely to increase one's chance of getting a job, it emerges that most South Africans are still not getting this rare opportunity of studying beyond Matric.

Another paramount factor discussed reveals that upfront fees and increasing fees often lead students from poor households into debts and ultimately result in high drop- out rates. It is said that universities often come under extreme financial pressure and are forced to increase fees, leaving those who cannot afford it in the lurch. The massive number of drop- outs cost the country both financial and human resources needed for economic development. Regarding the NSFAS funding, it emerges that the financial aid scheme does not provide sufficiently to pull those at the bottom out of poverty. It is further argued that the financial aid scheme does not cover all the study needs the students might have. In 2008 it was discovered that only five institutions were able to cover $50 \%$ of study fees for students. However, most scholars and organisations highlight that the situation cannot be left unresolved as it perpetuates the inequalities of the past and the poverty in the country. It is argued that South Africa needs to open the doors of learning for all through free higher education until the attainment of an undergraduate qualification. The country needs to breed the skills and knowledge of all its citizens in order to grow the economy.

\section{Conclusion}

In conclusion one can argue that the paper successfully interrogated questions relating to why South Africans need free higher education. From the paper one gets a clear picture as to how far the country has progressed in expanding access to higher education, especially amongst the previously disadvantaged groups. A descriptive analysis of the number of students who drop-out due to financial difficulties was also included. Further discussions identified the discrepancies between what the National Students Financial Aid Scheme offers to students and what their total study costs amount to.

\section{References}

African National Congress (2007) 52 National Conference: Resolutions. 16 December-20 December 2007.

Branson, N, Leibbrandt, M. \& Zuze, T L (2009) The demand for tertiary education in South Africa. SALDRU. University of Cape Town: Final report.

Carrim, N. \& Wangenge-Ouma, G Higher education in South Africa: a report of higher education South Africa. Cape Town: British 
Council South Africa.

Department of Education (DoE) (2001) Draft national plan for higher education in South Africa. Pretoria: DoE.

Department of Higher Education \& Training (DHET) (2012) Green Paper for post- school education and training. Pretoria: DHET.

Department of Higher Education \& Training (2010) Report of the Ministerial Committee on the Review of the National Student Financial Aid Scheme. Pretoria: DHET.

De Villiers, P (2012) Removing financial obstacles for access to tertiary education. Transformational audit: The youth divided. [S1]: [Sn].

Higher Education South Africa (HESA) (2010) Higher education commitment to facilitate increased access to and affordability of higher education. In statement issued by HESA: 28 January 2010.

International Education Association of South Africa (IEASA). (n.d). South African Higher Education: Facts and Figures. [S1]: [Sn].

Letseka, M. \& Maile, S (2008) High University drop-out rates: A threat to South Africa's future. HSRC policy brief. Pretoria: HSRC.

Lubisi, R C (2008) The quest for free education in South Africa: How close is the dream to the reality. Center for Education Policy Development. Constitutional Hill, 17 June 2008 (in speech).

Mdepa, W. \& Tshiwula, L (2012) Student diversity in South African higher education. Widening participation and lifelong learning. Volume, 13: 19- 33.

Mouton, N. Louw, G.P. \& Strydom, G L (2013) Present-day dillemas and challenges of the South African tertiary System. International business and economics journal. 12 (3): 285- 300.

OECD. 2008. Reviews of national policies on education: South Africa. Paris: OECD publishing.

National Student Financial Aid Scheme (NSFAS). 2012. NSFAS transformation programme. Presentation to the portfolio committee on higher education and Training. National Assembly: 04 September 2012.

Republic of South Africa (RSA) (1999) National Student Financial Aid Scheme Act No 56 of 1999. Republic of South Africa Government Gazette.

Statistics South Africa (STATS SA) (2012) Subjective poverty in South Africa: Findings of the living conditions survey. Pretoria: Statistics South Africa.

Statistics South Africa (STATS SA) (2012) Income and expenditure of households 2010/ 2011. Pretoria: Statistics South Africa.

Statistics South Africa (STATS SA) (2011) Living conditions of households in SA 2008/ 2009. Pretoria: Statistics South Africa.

Wangenge-Ouma, G (2012) Tuition fees and the challenge of making higher education a popular commodity in South Africa. HIGHER EDUCATION, Online First, April 28. DOI: 10.1007/s10734-012-9531-6.

Woodhall, M (2007) Funding higher education: the contribution of economic thinking to debate and policy thinking. Education working paper. No 8. 
